\title{
FORMULASI SEDIAAN KRIM KOMBINASI EKSTRAK DAUN SELEDRI (Apium graveolens L.) DAN DAUN JATI (Tectona grandis Linn.F) SEBAGAI ANTIBAKTERI TERHADAP Staphylococcus aureus.
}

\section{CREAM FORMULATION OF COMBINATION OF CELERY LEAF EXTRACT (Apium graveolens L.) AND TEAK LEAF EXTRACT (Tectona grandis Linn.F) AS ANTIBACTERIAL AGAINST Staphylococcus aureus.}

\author{
Riska Tuloli ${ }^{1)}$, Hosea J. Edy ${ }^{1)}$, Imam Jayanto ${ }^{1)}$ \\ ${ }^{1)}$ Program Studi Farmasi FMIPA UNSRAT Manado, 95115
}

\begin{abstract}
Celery plants (Apium graveolens L.) and teak plants (Tectona grandis Linn.f) are plants that contain flavonoids, tannins, and saponins and has antibacterial activity against Staphylococcus aureus. This study aims to test the antibacterial effectiveness of combination of celery and teak leaf cream and evaluate cream with parameters of physical tests (organoleptic, homogeneity, $\mathrm{pH}$, spreadability, adhesion) and physical stability with cycling test method. This study used an experimental laboratory method by making 5 variations concentration of extracts. Celery and teak leaf extract was extracted by maceration method. Antibacterial test used the wells method. Results of the evaluation of physical tests for organoleptic test (odor: a typical combination of extracts;color: brown; shape: semi-solid), homogeneity test (homogeneous), average of pH test is 6.02 , dispersion test is $4.27 \mathrm{~cm}$, adhesion test is 18.42 seconds. Based on the results of this study, concluded that the combination of celery leaf and teak leaf extract can be formulated into a cream. The cream of combination of celery and teak leafs extract are bacteriostatic and has antibacterial activity with an average diameter for formulation I $13.4 \mathrm{~mm}$, formulation II $9.23 \mathrm{~mm}$, formulation III $16.23 \mathrm{~mm}$, formulation IV $11 \mathrm{~mm}$, and formulation V $12.06 \mathrm{~mm}$.
\end{abstract}

Keywords : Celery (Apium graveolens L.), Teak (Tectona grandis Linn.f), Antibacterial, Cream.

\begin{abstract}
ABSTRAK
Tanaman seledri (Apium graveolens L.) dan tanaman jati (Tectona grandis Linn.f) merupakan tanaman yang mengandung flavonoid, tanin dan saponin dan memiliki aktivitas antibakteri terhadap Staphylococcus aureus. Penelitian ini bertujuan untuk menguji aktivitas antibakteri sediaan krim kombinasi ekstrak daun seledri dan daun jati serta mengevaluasi sediaan krim dengan parameter uji sifat fisik (uji organoleptik, uji homogenitas, uji $\mathrm{pH}$, uji daya sebar, uji daya lekat) dan stabilitas fisik dengan metode cycling test. Penelitian ini menggunakan metode eksperimental laboratorium dengan membuat 5 variasi konsentrasi ekstrak. Ekstrak diperoleh dengan cara maserasi. Uji antibakteri dilakukan dengan metode sumuran. Hasil evaluasi sifat fisik untuk uji organoleptik (bau: khas kombinasi ekstrak;warna:coklat;bentuk:setengah padat), uji homogenitas (susunan homogen), rata-rata uji pH 6,02, daya sebar 4,27 cm, daya lekat 18,42 detik. Berdasarkan hasil penelitian disimpulkan bahwa kombinasi ekstrak daun seledri dan daun jati dapat diformulasikan menjadi sediaan krim. Sediaan krim kombinasi ekstrak daun seledri dan daun jati bersifat bakteriostatik dan memiliki aktivitas antibakteri dengan diameter rata-rata untuk formula I 13,4 $\mathrm{mm}$, formula II 9,23 mm, formula III 16,23 mm, formula IV $11 \mathrm{~mm}$, dan formula V 12,06 mm.
\end{abstract}

Kata Kunci : Seledri (Apium graveolens L.), Jati (Tectona grandis Linn.f), Antibakteri, Krim. 


\section{PENDAHULUAN}

Mikroba dapat menyebabkan infeksi terhadap seseorang dan bersifat sangat dinamis. Mikroba bertahan hidup dengan cara menyebar atau berpindah tempat dan berkembang biak pada suatu reservoir baru. Salah satu bakteri penyebab infeksi yaitu Staphylococcus aureus, dimana infeksi ini ditandai dengan kerusakan jaringan yang disertai abes bernanah. Bisul, jerawat, serta infeksi pada luka merupakan contoh penyakit infeksi yang disebabkan oleh Staphylococcus aureus (Warsa, 1994).

Masyarakat Indonesia lebih banyak mengenal dan memilih menggunakan tanaman berkhasiat obat sebagai upaya untuk mengobati masalah kesehatan dibandingkan pelayanan kesehatan formal dengan obat-obatan moderen. Indonesia memiliki banyak tanaman dan hewan yang berpotensi sebagai zat aktif dalam pembuatan obat baru seperti Tagetes erecta Linn., Lantana camara Linn., bahkan cacing atau Lumbricus sp (Edy dan Parwanto, 2019; Parwanto, 2017; Parwanto et al., 2016). Salah satu tanaman obat yang teridentifikasi dan mungkin sangat berpotensi sebagai sumber baru untuk terapi adalah tanaman kombinasi daun seledri (Apium graveolens L.) dan daun jati (Tectona grandis Linn.f).

Seledri merupakan tanaman setahun atau dua tahun yang berbentuk semak atau rumput, memiliki aroma khas mentol dan merupakan tanaman jenis sayuran. Seledri memiliki kandungan beberapa senyawa yang bermanfaat seperti flavonoid, saponin, tanin, minyak atsiri yang berfungsi sebagai antibakteri (Kusnadi dan Devi, 2017). Ekstrak seledri dapat menghambat pertumbuhan Staphylococcus aureus sebesar 22,2 mm dengan penggunaan konsentrasi ekstrak sebesar 4\% (Khaerati dan Ihwan, 2011).

Tanaman jati (Tectona grandis Linn.f) adalah salah satu jenis pohon yang kayunya terkenal di dunia yang mengandung senyawa karbohidrat, alkaloid, tanin, sterol, saponin, protein, kalsium, fosfor, serat mentah dan juga mengandung pewarna (cokelat kekuningan atau kemerahan) (Dalimartha, 2008). Ekstrak etanol daun jati terbukti dapat menghambat pertumbuhan bakteri Staphylococcus aureus pada konsentrasi 25\% sebesar 11,2 $\mathrm{mm}$ (Fathinatullabibah et al., 2014).

Untuk memudahkan pemanfaatan kedua tanaman tersebut sebagai antibakteri, maka dibuat dalam bentuk formulasi sediaan krim. Krim adalah bentuk sediaan setengah padat yang mengandung satu atau lebih bahan obat terlarut atau terdispersi dalam bahan dasar yang sesuai dan mempunyai dua tipe yaitu air dalam minyak A/M, dan minyak dalam air M/A (Depkes, 1995). Dalam penelitian ini akan dibuat sediaan farmasi krim tipe minyak dalam air atau M/A karena krim tipe $\mathrm{M} / \mathrm{A}$ mempunyai keunggulan yaitu memberikan efek optimum karena mampu menaikkan gradien konsentrasi zat aktif yang menembus kulit sehingga absorpsi perkutan menjadi meningkat (Engelina, 2013). Krim dibuat dengan 5 variasi konsentrasi ekstrak yaitu $1: 4 \%, 4: 1 \%, 2,5: 2,5 \%, 2: 3 \%, 3: 2 \%$ sebagai krim antibakteri lalu dievaluasi sifat fisik dan stabilitas. Pada penelitian sebelumnya, setelah disimpan selama 1 tahun sediaan krim dengan zat aktif L. camara Linn. masih memiliki stabilitas fisik yang baik (Mahardhitya dan Parwanto, 2018).

\section{METODOLOGI PENELITIAN}

\section{Waktu dan Tempat Penelitian}

Penelitian dilaksanakan pada bulan Desember 2019 - Juni 2020 di Laboratorium Farmasi Lanjutan, Program Studi Farmasi, Fakultas Matematika dan Ilmu Pengetahuan Alam, Universitas Sam Ratulangi, Manado.

\section{Alat dan Bahan}

Peralatan yang digunakan dalam penelitian ini ialah oven, timbangan analitik, blender, batang pengaduk, gelas ukur, corong, gelas kimia, kamera, label, hot plate, inkubator, 
(Laminari Air Flow) LAF, cawan petri, pH meter, autoklaf, erlenmeyer, tabung reaksi, mistar, wadah krim, wadah ekstrak, dan ayakan.

Bahan yang digunakan dalam penelitian ini ialah daun seledri, daun jati, etanol 96\%, Nutrien Agar (NA), asam stearat, setil alkohol, gliserin, triethanolamine (TEA), paraffin cair, aquades, bakteri Staphylococccus aureus, hydrochloric acid $(\mathrm{HCl})$ pekat, natrium klorida $(\mathrm{NaCl})$, ferric chloride ( $\mathrm{FeCl} 3)$, Serbuk Magnesium, asam sulfat ( $\mathrm{H} 2 \mathrm{SO} 4)$, barium chloride dihydrate $(\mathrm{BaCl} 2.2 \mathrm{H} 2 \mathrm{O})$.

\section{Prosedur Penelitian}

\section{Persiapan Sampel}

Masing-masing sampel dari daun seledri dan daun jati dikumpulkan dan dibersihkan dengan air mengalir kemudian di angin-anginkan hingga kering. Sampel yang sudah kering kemudian dihaluskan menggunakan blender dan di ayak sampai menjadi serbuk simplisia (Edy et al., 2019).

\section{Pembuatan Ekstrak}

Pembuatan ekstrak dibuat dengan metode maserasi. Masing-masing simplisia daun seledri dan daun jati direndam dengan etanol 96\% dan didiamkan selama 4 hari sambil sesekali diaduk. Setelah didiamkan, disaring dengan kertas saring dan menghasilkan filtrat 1 dan residu 1. Residu diambil dan dimaserasi lagi menghasilkan filtrat 2 dan residu 2. Filtrat 1 dan 2 kemudian dicampur dan diuapkan dalam oven dengan suhu $40^{\circ} \mathrm{C}$ sampai diperoleh ekstrak kental (Edy et al., 2019).

\section{Formulasi Krim}

Timbang semua bahan sesuai dengan formula yang ada kemudian fase minyak (asam stearat, setil alkohol, parafin cair) dan fase air (gliserin, TEA, aquades) secara terpisah dipanaskan di atas hot plate pada suhu $60-70^{\circ} \mathrm{C}$. Pemanasan dilakukan hingga fase minyak melebur dan fase air melarut seluruh komponennya. Setelah itu dimasukkan fase minyak sedikit demi sedikit kedalam lumpang panas yang berisi fase cair dan digerus hingga terbentuk basis krim. Bila suhu krim sudah mencapai suhu $\pm 45^{\circ} \mathrm{C}$ tambahkan ekstrak daun seledri dan ekstrak daun jati pada basis krim dan diaduk hingga homogen kemudian krim dimasukkan kedalam wadah (Wulandari et al., 2017).

\section{Uji Aktivitas Antibakteri}

Uji aktivitas antibakteri menggunakan metode difusi agar (difusi kirby dan baeur yang dimodifikasi) dengan cara sumuran yang terdiri dari 2 lapisan media agar. Lapisan agar yang pertama dibuat dengan menuangkan $50 \mathrm{ml} \mathrm{NA}$ ke dalam cawan petri, dibiarkan memadat dan ditanamkan pencadang. Lapisan agar yang kedua dibuat dengan menuangkan masing-masing 50 ml NA yang sudah ditambahkan suspensi bakteri ke dalam cawan petri dan dibiarkan memadat. Pencandang diangkat secara aseptik menggunakan pinset dari masing-masing cawan petri, sehingga terbentuk sumur-sumur . Sebanyak 0,1 gram krim masing-masing konsentrasi, kontrol positif (krim gentamicin) dan kontrol negatif (basis krim) dimasukkan kedalam sumur yang berbeda. Dilakukan inkubasi pada suhu $37^{\circ} \mathrm{C}$ selama 24 jam lalu diamati zona bening yang terbentuk.

\section{Evaluasi Sifat Fisik Krim}

a. Uji Organoleptik

Evaluasi organoleptis menggunakan panca indra mulai dari bentuk, bau, dan warna. Parameter kualitas fisik krim yaitu tidak terjadi perubahan bentuk, warna dan bau semenjak dari awal pembuatan, pada saat penyimpanan sampai zat tersebut digunakan (Wardiyah, 2015).

b. Uji Homogenitas

Pemeriksaan homogenitas dilakukan untuk melihat tercampurnya bahan-bahan sediaan krim. Sebanyak 1 gram krim dioleskan pada sekeping kaca transparan dan diamati. Sediaan harus menunjukan susunan yang 
homogen dan tidak terlihat adanya butiran kasar (Lubis et al., 2012).

\section{c. Uji pH}

Uji $\mathrm{pH}$ bertujuan mengetahui keamanan sediaan krim saat digunakan sehingga tidak mengiritasi kulit. Ditimbang sebanyak 1 gram ekstrak krim dan diencerkan dengan $10 \mathrm{ml}$ aquades. Gunakan pH-meter yang bagian sensornya dan dibaca $\mathrm{pH}$ pada bagian monitor. $\mathrm{pH}$ sediaan yang memenuhi kriteria $\mathrm{pH}$ kulit yaitu dalam interval 4,5 - 6,5 (Djajadisastra et al., 2007; Parwanto et al., 2013; Edy et al., 2016).

\section{d. Uji Daya Sebar}

Ditimbang 0,5 gram krim. Letakkan krim tersebut ditengah cawan petri yang berada dalam posisi terbalik. Diamkan selama 1 menit dan ditambahkan beban 50 gram sampai 250 gram setiap 1 menit dan ukur diameternya. Standar daya sebar krim yaitu $5 \mathrm{~cm}-7 \mathrm{~cm}$ (Wasiaatmadja, 1997; Parwanto et al., 2013; Edy et al., 2016).

e. Uji Daya Lekat

Uji daya lekat dilakukan dengan cara 0,5 gram krim dioleskan pada plat kaca. Kedua plat kaca ditempelkan hingga plat menyatu dan diberikan beban seberat 250 gram selama 5 menit kemudian dilepaskan. Dicatat waktu sampai kedua plat saling lepas. Standar daya lekat krim yang baik yaitu >4 detik (Wasiaatmadja, 1997; Parwanto et al., 2013; Edy et al., 2016).

\section{f. Uji Stabilitas}

Uji stabilitas atau cycling test ini merupakan salah satu cara mempercepat evaluasi kestabilan fisik yang dilakukan sebanyak 6 siklus. Krim disimpan pada suhu dingin $\pm 4^{\circ} \mathrm{C}$ selama 24 jam lalu dikeluarkan dan ditempatkan pada suhu $\pm 40^{\circ} \mathrm{C}$ selama 24 jam ( 1 siklus ). Kondisi fisik krim yaitu organoleptik, homogenitas, $\mathrm{pH}$, daya sebar dan daya lekat selama cycling test dibandingkan dengan hasil sebelumnya (Dewi, 2010).

\section{HASIL DAN PEMBAHASAN Ekstraksi}

Ekstrak kental yang diperoleh dari hasil penguapan dalam oven sebanyak 76,3 gram untuk daun seledri dengan persen rendemen sebesar 19,075 \% dan ekstrak kental daun jati sebanyak 43,2 gram dengan persen rendemen sebesar 10,8\%.

\section{Formulasi Krim}

Formula krim kombinasi ekstrak daun seledri dan daun jati yang ada diperoleh dengan cara menambahkan fase minyak kedalam fase cair kemudian ditambahkan kombinasi ekstrak. Krim yang ada diuji untuk aktivitas antibakterinya apakah tergolong kuat sedang atau lemah.

\section{Uji Antibakteri}

Hasil pengujian antibakteri dapat dilihat pada Gambar 1.

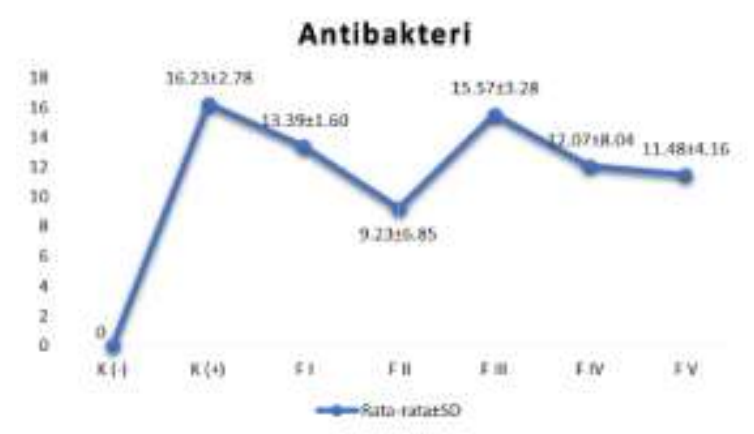

Gambar 1. Hasil pengujian antibakteri.

Pengujian antibakteri sediaan krim bertujuan untuk mengetahui daya hambat sediaan krim terhadap bakteri Staphylococcus aureus dan mengetahui perbandingan formulasi sediaan yang memberikan nilai aktivitas antibakteri tertinggi. Pengujian antibakteri dilakukan sebanyak 3 kali pengulangan pada masing-masing krim. Terbentuknya zona hambat disekitar sumuran menandakan bahwa tidak ada pertumbuhan bakteri di media NA yang berarti krim tersebut memiliki sifat antibakteri. Hasil yang diperoleh yaitu krim kombinasi ekstrak daun 
seledri dan daun jati formulasi I (1:4\%) memiliki daya hambat sebesar $13,4 \mathrm{~mm}$, formulasi II $(4: 1 \%)$ memiliki daya hambat sebesar 9,23 $\mathrm{mm}$, formulasi III $(2,5: 2,5 \%)$ memiliki daya hambat sebesar $16,23 \mathrm{~mm}$, formulasi IV (2:3\%) memiliki daya hambat sebesar $11 \mathrm{~mm}$, dan formulasi $\mathrm{V}(3: 2 \%)$ memiliki daya hambat 12,06 $\mathrm{mm}$. Dari hasil diatas menunjukkan bahwa formulasi III lah yang memberikan efek antibakteri terbesar dan dikatakan kuat karena memiliki daya hambat sebesar $16,23 \mathrm{~mm}$ atau perbandingan kombinasi ekstrak daun seledri dan ekstrak daun jati sebanyak 2,5\%:2,5\%.

\section{Evaluasi Sifat Fisik Krim}

\section{a. Uji Organoleptik}

Pada uji organoleptik bertujuan untuk melihat warna, bentuk serta bau dari sediaan krim kombinasi ekstrak daun seledri dan daun jati secara visual. Hasil uji organoleptik dapat dilihat pada Tabel 1.

Tabel 1. Hasil uji organoleptik siklus 0 .

\begin{tabular}{ccll}
\hline Pengulangan Bentuk & \multicolumn{1}{c}{ Bau } & Warna \\
\hline \multirow{4}{*}{1} & $\begin{array}{l}\text { Semi } \\
\text { padat }\end{array}$ & $\begin{array}{l}\text { Khas } \\
\text { Kombinasi }\end{array}$ & Coklat \\
& Ekstrak & \\
& Semi & Khas & \\
2 & padat & Kombinasi & Coklat \\
& Ekstrak & \\
& Semi & Khas & \\
& Kombinasi & Coklat \\
3 & Ekstrak & \\
\hline
\end{tabular}

Dapat dilihat pada hasil dari tiap pengulangan krim mempunyai warna yang coklat, dari segi bentuk krim mempunyai bentuk semi padat seperti krim pada umumnya dan krim mempunyai bau khas ekstrak yang berasal dari daun seledri dan daun jati.

b. Uji Homogenitas

Uji homogenitas bertujuan untuk melihat susunan yang homogen dari sediaan krim yang dibuat. Hasil uji homogenitas dapat dilihat pada Tabel 2.

Tabel 2. Hasil uji homogenitas siklus 0.

\begin{tabular}{cc}
\hline Pengulangan & Homogenitas \\
\hline 1 & Homogen \\
2 & Homogen \\
3 & Homogen \\
\hline
\end{tabular}

Dapat dilihat pada hasil setelah 3 kali pengulangan sediaan krim kombinasi ekstrak daun seledri dan daun jati menunjukkan susunan yang homogen dan tidak terlihat butiran-butiran kasar.

c. Uji pH

Uji $\mathrm{pH}$ bertujuan untuk mengetahui sifat keasaman sediaan krim kombinasi ekstrak daun seledri dan daun jati yang dibuat sehingga saat di aplikasikan ke kulit tidak mengiritasi dan aman untuk digunakan. Hasil dari pengujian $\mathrm{pH}$ bisa dilihat pada Tabel 3 .

Tabel 3 Hasil uji pH siklus 0.

\begin{tabular}{|c|c|}
\hline Pengulangan & $\mathbf{p H}$ \\
\hline 1 & 6.31 \\
\hline 2 & 6.28 \\
\hline 3 & 5.83 \\
\hline Rata-rata \pm SD & $6.14 \pm 0.27$ \\
\hline
\end{tabular}
pengulangan pada siklus 0 mempunyai ratarata 6,14 yang berarti sediaan krim yang dibuat sesuai dengan $\mathrm{pH}$ kulit, aman dan tidak mengiritasi kulit karena sesuai dengan teori bahwa $\mathrm{pH}$ sediaan yang memenuhi kriteria $\mathrm{pH}$ kulit yaitu dalam interval 4,5 - 6,5 (Djajadisastra et al., 2007; Parwanto et al., 2013; Edy et al., 2016).

d. Uji Daya Sebar

Pada uji daya sebar ini bertujuan untuk mengetahui kemampuan penyebaran sediaan krim yang dibuat pada permukaan kulit saat diaplikasikan. Daya sebar yang baik menyebabkan kontak antara obat dengan kulit menjadi luas, sehingga absorpsi obat ke kulit 
berlangsung cepat. Hasil pengujian daya sebar bisa dilihat pada Tabel 4 .

Tabel 4. Hasil uji daya sebar siklus 0 .

\begin{tabular}{cc}
\hline Pengulangan & Daya Sebar $(\mathbf{c m})$ \\
\hline 1 & 4.4 \\
2 & 4.3 \\
3 & 4.4 \\
\hline
\end{tabular}

\begin{tabular}{cc}
\hline Rata-rata \pm SD & $4.37 \pm 0.06$ \\
\hline Hasil dari uji daya sebar setelah
\end{tabular}
dilakukan 3 kali pengulangan mempunyai rata-rata $4,37 \mathrm{~cm}$. Hasil ini tidak sesuai dengan teori karena krim yang baik akan menghasilkan daya sebar sebesar 5-7 cm (Wasiaatmadja, 1997). Hal ini dapat disebabkan oleh penambahan ekstrak yang banyak sehingga menyebabkan krim semakin pekat dan daya sebarnya menurun (Widyaningrum, 2012; Parwanto et al., 2013; Edy et al., 2016).

e. Uji Daya Lekat

Pada pengujian daya lekat bertujuan untuk megetahui kemampuan sediaan krim untuk melekat pada kulit saat diaplikasikan. Hasil uji daya lekat bisa dilihat pada Tabel 5.

Tabel 5. Hasil uji daya lekat siklus 0 .

\begin{tabular}{cc}
\hline Pengulangan & Daya Lekat (detik) \\
\hline 1 & 12.21 \\
2 & 22.02 \\
3 & 25.25 \\
\hline
\end{tabular}

\begin{tabular}{l}
\hline Rata-rata \pm SD \\
\hline Hasil dari uji daya lekat setelah 3 kali \\
pengulangan mempunyai rata-rata 19,83 detik \\
yang berarti sediaan krim kombinasi ekstrak \\
daun seledri dan daun jati memiliki daya lekat \\
yang baik. Hasil ini sesuai dengan teori \\
bahwa krim yang baik yaitu daya lekat nya \\
lebih dari 4 detik karena semakin lama krim \\
melekat pada kulit maka semakin banyak zat \\
aktif yang diabsorbsi (Wasiaatmadja, 1997; \\
Parwanto et al., 2013; Edy et al., 2016). \\
f. Uji Stabilitas
\end{tabular}

Hasil uji organoleptik selama cycling test dapat dilihat pada Tabel 6.

Tabel 6. Hasil uji organoleptik siklus 1-6.

\begin{tabular}{|c|c|c|}
\hline Pengulangan Bentuk & Bau & Warna \\
\hline $\begin{array}{l}\text { Semi } \\
\text { padat }\end{array}$ & $\begin{array}{l}\text { Khas } \\
\text { Kombinasi } \\
\text { Ekstrak }\end{array}$ & Coklat \\
\hline $\begin{array}{l}\text { Semi } \\
\text { padat }\end{array}$ & $\begin{array}{l}\text { Khas } \\
\text { Kombinasi } \\
\text { Ekstrak }\end{array}$ & Coklat \\
\hline $\begin{array}{l}\text { Semi } \\
\text { padat }\end{array}$ & $\begin{array}{l}\text { Khas } \\
\text { Kombinasi } \\
\text { Ekstrak }\end{array}$ & Coklat \\
\hline
\end{tabular}

Dapat dilihat pada hasil diatas sediaan krim kombinasi ekstrak daun seledri dan daun jati memenuhi standar uji stabilitas. Sediaan krim saat diuji organoleptik kembali tidak mengalami perubahan baik dari sergi bentuk, bau dan warna.

Hasil uji homogenitas selama cycling test dapat dilihat pada Tabel 7.

Tabel 7. Hasil uji homogenitas siklus 1-6.

\begin{tabular}{cc}
\hline Pengulangan & Homogenitas \\
\hline 1 & Homogen \\
2 & Homogen \\
3 & Homogen \\
\hline
\end{tabular}

Dapat dilihat pada hasil bahwa sediaan krim kombinasi ekstrak daun seledri dan daun jati tidak mengalami perubahan homogenitas selama cycling test. Sediaan krim tetap mempunyai susunan yang homogen, tidak adanya butiran kasar dan tidak mengalami pemisahan antara fase minyak dan fase cair sehingga krim dikatakan stabil dari segi homogenitas.

Hasil uji $\mathrm{pH}$ krim selama cycling test dapat dilihat pada Gambar 2. 


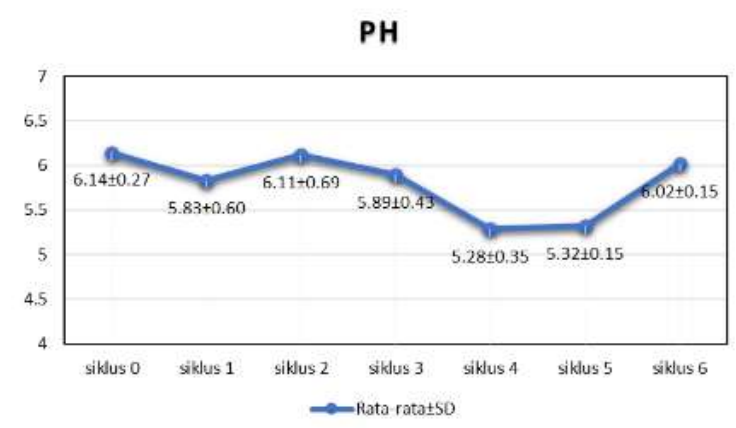

Gambar 2. Hasil Uji pH Sebelum dan Selama Cycling test

Dapat dilihat pada hasil bahwa $\mathrm{pH}$ sediaan krim kombinasi ekstrak daun seledri dan daun jati selama cycling test masuk dalam kategori $\mathrm{pH}$ krim yang baik. Terjadi penurunan dan kenaikan dari nilai $\mathrm{pH}$ di atas karena pengaruh perubahan suhu yang ada (Rabima dan Marshall, 2017). Hasil statistika menunjukkan tidak ada perbedaan yang bermakna dari $\mathrm{pH}$ krim sebelum dan sesudah uji stabilitas karena menunjukkan nilai Sig.(2tailed) 0,527 sehingga krim dikatakan stabil dari segi $\mathrm{pH}$.

Hasil uji daya sebar selama cycling test dapat dilihat pada Gambar 3.

Daya Sebar

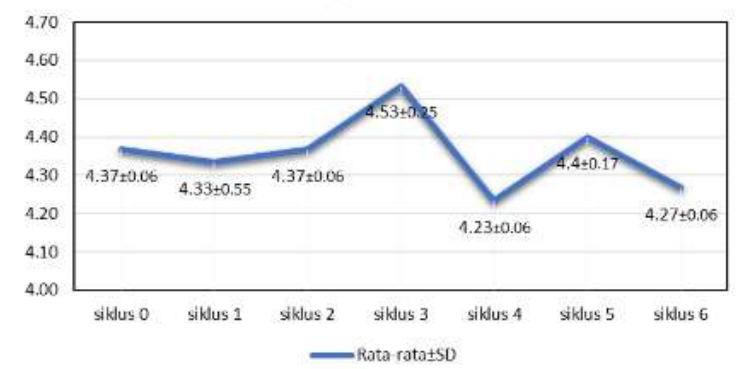

Gambar 3. Hasil Uji Daya Sebar Sebelum dan Selama Cycling test

Dapat dilihat pada hasil bahwa nilai daya sebar yang didapat sebelum dan selama cycling test masih tidak masuk dalam kriteria daya sebar krim yang baik yaitu lebih dari 5 $\mathrm{cm}$. Daya sebar krim mengalami kenaikan dan penurunan selama proses cycling test namun tidak jauh berbeda dengan nilai pada siklus 0 . Perubahan daya sebar krim ini dipengaruhi karena perubahan suhu selama penyimpanan sehingga terjadi perubahan viskositas krim yang menyebabkan daya sebar berbeda (Zulkarnain et al., 2013). Hasil statistika uji daya sebar menunjukkan tidak ada perbedaan yang bermakna dari daya sebar krim sebelum dan sesudah uji stabilitas karena menunjukkan nilai Sig.(2-tailed) 0,101 sehingga krim dikatakan stabil dari segi daya sebar.

Hasil uji daya lekat krim dapat dilihat pada Gambar 4.

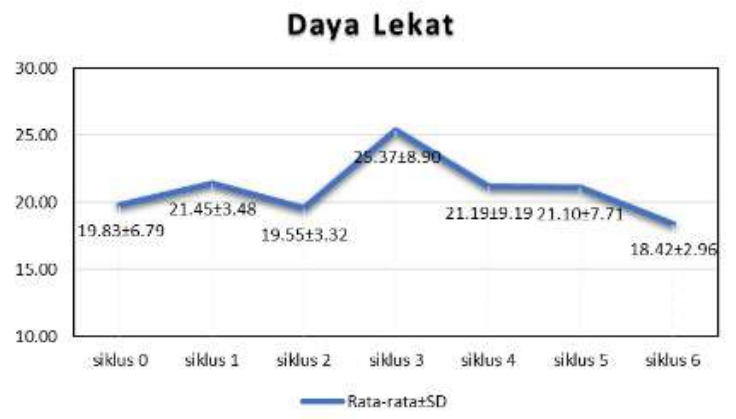

Gambar 4. Hasil Uji Daya Lekat Sebelum dan Selama Cycling test

Dapat dilihat pada hasil bahwa daya lekat krim mengalami kenaikan serta penurunan daya lekat selama proses cycling test. Seperti halnya dengan daya sebar, daya lekat krim ini mengalami perubahan karena pengaruh suhu selama penyimpanan yang menyebabkan viskositas krim berubah. Nilai dari masing-masing siklus pada daya lekat krim selama proses cycling test memenuhi syarat karena mempunyai nilai lebih dari 4 detik. Hasil statistika uji daya lekat menunjukkan tidak ada perbedaan yang bermakna dari daya lekat krim sebelum dan sesudah cycling test karena menunjukkan nilai Sig.(2-tailed) 0,758 yang berarti krim dikatakan stabil dari segi daya lekat. 


\section{KESIMPULAN}

Berdasarkan hasil penelitian yang telah dilakukan dapat disimpulkan bahwa kombinasi ekstrak daun seledri (Apium graveolens L.) dan daun jati (Tectona grandis Linn.f) dapat diformulasikan menjadi sediaan krim. Sediaan krim kombinasi ekstrak daun seledri dan daun jati bersifat bakteriostatik dan memiliki aktivitas antibakteri dengan diameter rata-rata untuk formulasi I (1\%:4\%) $13,4 \mathrm{~mm}$, formulasi II $(4 \%: 1 \%) 9,23 \mathrm{~mm}$, formulasi III $(2,5 \%: 2,5 \%) \quad 16,23 \mathrm{~mm}$, formulasi IV (2\%:3\%) $11 \mathrm{~mm}$, dan formulasi $\mathrm{V}(3 \%: 2 \%) 12,06 \mathrm{~mm}$.

\section{SARAN}

Disarankan kepada peneliti selanjutnya untuk melakukan uji fisik yang belum dilakukan dalam penelitian seperti yaitu uji viskositas dan uji iritasi .

\section{DAFTAR PUSTAKA}

Dalimartha, S. 2008. Atlas Tumbuhan Obat Indonesia. Niaga Swadaya, Jakarta.

Depkes. 1995. Farmakope Indonesia Edisi ke 4. Departemen Kesehatan RI, Jakarta.

Dewi, R.K. 2010. Optimasi Formulasi Mikroemulsi Sediaan Hormon Testosteron Undekanoat [skripsi]. Fakultas Matematika dan Ilmu Pengetahuan Alam, Universitas Islam Negeri Syarif Hidayatullah, Jakarta.

Djajadisastra, J., R.I. Tranggono., F. Latifah. 2007. Buku Pegangan Ilmu Pengetahuan. Kosmetik. Gramedia, Jakarta.

Engelina, N.G. 2013. Optimasi Krim Sarang Burung Walet Putih (Aerodramus Fuciphagus) Tipe M/A dengan Variasi Emulgator Sebagai Pencerah Kulit Menggunakan Simplex Lattice Design [skripsi]. Fakultas Kedokteran Universitas Tanjungpura, Pontianak.

Edy, H.J., dan M.L.E. Parwanto. 2019. Pemanfaatan Tanaman Tagetes erecta Linn. dalam Kesehatan. Jurnal Biomedika dan Kesehatan. 2(2): 77-80.

Edy, H.J., Marchaban., S. Wahyuono., A.E. Nugroho. 2016. Formulasi dan Uji Sterilitas Hidrogel Herbal Ekstrak Etanol Daun Tagetes erecta L. Pharmacon. 5(2): 9-16.

Edy, H.J., Marchaban., S. Wahyuono., A.E. Nugroho. 2019. Pengujian Aktivitas Antibakteri Hidrogel Ekstrak Etanol Daun Tagetes erecta L. Jurnal MIPA. 8(3): 96-98.

Fathinatullabibah, F., L.U. Khasanah., K. Kawiji. 2014. Stabilitas Antosianin Ekstrak Daun Jati (Tectona grandis) terhadap Perlakuan $\mathrm{pH}$ dan Suhu. J. Apl. Teknol. Pangan 3. 3(2): 60-63.

Khaerati, K., I. Ihwan. 2011. Uji Efek Antibakteri Ekstrak Etanol Herba Seledri (Apium graveolens L.) Terhadap Escherichia Coli Dan Staphylococcus aureus dan Analisis KLT Bioautografi. Biocelebes, 5(1): 13-21.

Kusnadi, K., E.T., Devi. 2017. Isolasi Dan Identifikasi Senyawa Flavanoid Pada Ekstrak Daun Seledri (Apium graveolens L.) Dengan Metode Refluks. Pancasakti Science Education Journal. 2(9): 56-67.

Lubis, E.S., L.S. Lubis., J. Reveny. 2012. Pelembab Kulit Alami Dari Sari Buah Jeruk Bali. Journal of Pharmaceutics and Pharmacology. 3(1): 8-13.

Mahardhitya, M.R., dan M.L.E. Parwanto. 2018. Krim Ekstrak Daun Lantana camara Linn. 4\% Stabil Setelah Disimpan 1 Tahun. Jurnal Biomedika dan Kesehatan. 1(1): 50-57. 
Parwanto, M.L.E. 2003. Efficcacy of Lantana camara Linn. Leaf Extracts Ointment on Dermal Wound Healing Were Infected with Staphylococcus epidemidis. International Journal of Basic \& Clinical Pharmacology. 6(3): 77-80.

Parwanto, M.L.E., Mahyunis., H. Senjaya., H.J. Edy., Syamsurizal. 2016. Fractionation and Characterization of Proteins in Lumbricus rubellus Powders. International Journal of Pharmceutical and Clinical Reserch. 8(1): $15-21$

Parwanto, M.L.E., H. Senjaya., H.J. Edy. 2013. Formulasi Salep Antibakteri Ekstrak Etanol Daun Tembelekan (Lantana camara L.). Pharmacon. 1(1): 104-108.

Rabima dan Marshall. 2017. Uji Stabilitas Formulasi Sediaan Krim Antioksidan Ekstrak Etanol 70\% Dari Biji Melinjo (Gnetum gnemon L.). Indonesian Natural Research Pharmaceutical Journal. 2(1): 107-121.

Wardiyah, S. 2015. Perbandingan Sifat Fisik Sediaan Krim, Gel, Dan Salep Yang
Mengandung Etil P-Metoksisinamat Dari Ekstrak Rimpang Kencur (Kaempferia galanga Linn.) [thesis]. Fakultas Kedokteran dan Ilmu Kesehatan, Universitas Islam Negeri Syarif Hidayatullah, Jakarta.

Warsa U.C. 1994. Staphylococcus Dalam Buku Ajar Mikrobiologi Kedokteran. Binarupa Aksara. Jakarta.

Wasitaatmadja, S.M. 1997. Penuntun Ilmu Kosmetik Medik. Universitas Indonesia, Jakarta.

Wulandari, S.S., M.R.J. Runtuwene., D.S. Wewengkang. 2017. Aktivitas Perlindungan Tabir Surya Secara in Vitro Dan in Vivo Dari Krim Ekstrak Etanol Daun Soyogik (Saurauia bracteosa Dc). Jurnal Ilmiah Farmasi. 6(3): 147-156.

Widyaningrum, N., M. Murrukmihadi., S.K. Ekawati. 2012. Pengaruh Konsentrasi Ekstrak Etanolik Daun The Hijau (Camellia sinesis L.) dalam Sediaan Krim terhadap Sifat Fisik dan Aktivitas Antibakteri. Sains Medika. 4(2): 147156. 